GRASAS Y ACEITES 68 (1)

January-March 2017, e184

ISSN-L: 0017-3495

doi: http://dx.doi.org/10.3989/gya.1048162

\title{
Effects of thermal processing on physicochemical properties and oxidative stability of Balanities aegyptiaca kernels and extracted oil
}

\author{
S.M.A. Elbadawi ${ }^{\text {a }}$ E.E.M. Ahmad ${ }^{\mathrm{a}}$, A.A. Mariod ${ }^{\mathrm{b}, \mathrm{c}, \mathbb{}}$ and B. Mathäus $^{\mathrm{d}}$ \\ a Department of Chemistry, Sudan University of Science and Technology, Khartoum, Sudan. \\ ${ }^{b}$ Department of Biology, College of Science and Arts, University of Jeddah, Alkamil, KSA. \\ ${ }^{\mathrm{c}}$ Department of Food Science \& Technology, Sudan University of Science and Technology \\ Khartoum North, Sudan. \\ ${ }^{\mathrm{d}}$ Department for lipid research, Working Group for Lipid Research, Detmold, Germany. \\ ${ }^{\bowtie}$ Corresponding authors: basitmariod@yahoo.com; aalnadif@uj.edu.sa
}

Submitted: 11 October 2016; Accepted: 03 January 2017

\begin{abstract}
SUMMARY: In the present study, the effects of roasting and boiling on the proximate composition of the kernels as well as the physicochemical properties and oxidative stabilities of the extracted oils of Balanites aegyptiaca were investigated. Roasting was performed at $180{ }^{\circ} \mathrm{C}$ for 15 minutes, whereas boiling of the kernels was carried out in tap water for one hour. The oils from raw and thermally processed samples were extracted using $\mathrm{n}$-hexane in a Soxhlet extraction apparatus and characterized. The roasting significantly $(\mathrm{p}<0.05)$ influenced the peroxide value and the oxidative stability of the extracted oil in a positive way; whereas boiling had the opposite effect. The oils were composed of linoleic, oleic, stearic, and palmitic acids as the major fatty acids $(96 \%)$ and contained predominantly $\alpha$ - and $\gamma$-tocopherols (ca. $400 \mathrm{mg} / \mathrm{kg}$ ). The study suggests that the oil from roasted kernels could be used as a natural antioxidant for enhancing the characteristics of other edible oils via blending.
\end{abstract}

KEYWORDS: Balanities aegyptiaca; Boiling; Fatty acids; Oxidative Stability; Roasting; Tocols

RESUMEN: Efecto de tratamientos térmicos sobre las propiedades fisicoquímicas y estabilidad oxidativa de semillas de Balanities aegyptiaca y de los aceites extraídos. En el presente estudio se investigaron los efectos del tostado y ebullición sobre la composición proximal de las semillas, así como las propiedades fisicoquímicas y estabilidad oxidativa de los aceites extraídos de Balanites aegyptiaca. La torrefacción se realizó a $180{ }^{\circ} \mathrm{C}$ durante 15 minutos mientras que la ebullición de los granos se realizó en agua durante una hora. Los aceites de las muestras crudas y térmicamente procesadas se extrajeron utilizando n-hexano mediante Soxhlet y fueron caracterizados. La torrefacción influyó significativamente $(p<0,05)$ en el valor del peróxido y en la estabilidad oxidativa del aceite extraído, de manera positiva, mientras que la ebullición tiene el efecto opuesto. Los aceites contenían linoleico, oleico, esteárico y palmítico como principales ácidos grasos $(96 \%)$ y contenían predominantemente $\alpha$ - y $\gamma$-tocoferoles (aprox. $400 \mathrm{mg} / \mathrm{kg}$ ). El estudio sugiere que el aceite de granos tostados podría ser utilizado como un antioxidante natural para mejorar las características de otros aceites comestibles a través de la mezcla.

PALABRAS CLAVE: Ácidos grasos; Balanities aegyptiaca; Ebullición; Estabilidad oxidativa; Tocols; Tostado

ORCID ID: Elbadawi SMA http://orcid.org/0000-0002-4041-7084, Ahmad EEM http://orcid.org/0000-0003-12691315, Mariod AA http://orcid.org/0000-0003-3237-7948, Mathaus B http://orcid.org/0000-0002-9222-8939

Citation/Cómo citar este artículo: Elbadawi SMA, Ahmad EEM, Mariod AA, Mathäus B. 2017. Effects of thermal processing on physicochemical properties and oxidative stability of Balanities aegyptiaca kernels and extracted oil. Grasas Aceites 68, e184. http://dx.doi.org/10.3989/gya.1048162

Copyright: (C) 2017 CSIC. This is an open-access article distributed under the terms of the Creative Commons Attribution (CC-by) Spain 3.0 License. 


\section{INTRODUCTION}

Exploring new sources of oil has been of growing interest due to the rapid increase in consumption by the ever-growing human population, economic purposes, and diverse industrial applications (Chenga, et al. 2016; Vermaak, et al. 2011; Mariod, et al. 2004). Balanites aegyptiaca which is also known as "desert date" belongs to the family of Balanitaceae and species of the genus Balanites aegyptiaca ( $L$ ) Delile. It is widespread in most arid, semi-arid to sub-humid tropical savannas in Africa, all over the Sahel, extending from the Atlantic coastline of Senegal to the Red Sea, Indian Ocean, and the Arabian Peninsula (Maydell, 1990). In Sudan, it is commonly found in the dark cracking clays of central Sudan, often associated with Acacia seyal on the short grass savanna (El Amine, 1990).

Few articles have been published on the characteristics and potential applications of Balanites aegyptiaca oil. The findings have revealed interesting characteristics of this oil which makes it applicable in many areas including food, biodiesel, antimicrobial, and anti-ulcer (Al Ashaal, et al. 2010; Chapagain, 2009; Nour, et al. 1985). Al Ashaal et al. [2010] have studied the chemical composition and the biological activities of the fixed oil of Balanites aegyptiaca. Their results have shown that the oil has anticancer, antimutagenic, antiviral and antimicrobial activities. Despite the wide distribution of the Balanites aegyptiaca tree among almost all regions of Sudan and the amazing characteristics of its oil, limited attention has been given to this multi-purpose tree and its products, especially the oil. Thermal processing (roasting and boiling) is commonly used by local communities to obtain the oil. To the best of our knowledge, this is the first article to report on the influence of these treatments on the chemical composition of the kernels and the extracted oils as well as the fatty acid composition, and oxidative stability of the oil.

\section{MATERIALS AND METHODS}

\subsection{Sample collection and pretreatment}

A Balanites aegyptiaca sample was purchased from an Omdurman market (Souk Omdurman), Sudan, on January 2015. The epicarps of the Balanites aegyptiaca fruit were removed manually and the remaining edible flesh (mesocarp) plus the endocarps were soaked in tap water overnight. After complete removal of the edible flesh the endocarps were dried in sunlight for two days. Finally, the endocarps were removed manually using a hammer and the kernels were stored at $10{ }^{\circ} \mathrm{C}$ for the next steps.

\subsection{Pretreatment of the kernels}

\subsubsection{Boiling}

The kernels were immersed in boiling tap water at $100{ }^{\circ} \mathrm{C}$ at a ratio of $1: 4 \mathrm{kernel} /$ water for one hour in a $500 \mathrm{~mL}$ beaker with continuous heating and stirring until the pieces were well cooked. The cooked sample was dried and ground in a grinder (Ndidi, et al. 2014).

\subsubsection{Roasting}

Kernels were arranged in a single layer on an aluminium tray and placed in a KUMTEL electric oven (LX3520 T-INOX (with adjustable thermostat 80-320 ${ }^{\circ} \mathrm{C}$, homogeneous heat distribution, timer function), Turkey) at $180^{\circ} \mathrm{C}$ for 15 minutes and finally the sample was allowed to cool to ambient temperature, and stored at $10{ }^{\circ} \mathrm{C}$ (Mariod, et al. 2012).

\subsection{Proximate analysis}

Moisture, ash, protein, and lipids were determined following the standard methods of the Association of Official Analytical Chemists (AOAC) [1990]. In each case triplicate analyses were done and the mean and the standard deviation were calculated (mean $\pm \mathrm{SD}$ ). Total carbohydrates were determined by difference and the standard deviation was calculated using propagation of error.

\subsection{The physical properties of the oil}

\subsubsection{Determination of specific gravity}

An empty and a dry pycnometer were weighed and filled with distilled water at $25^{\circ} \mathrm{C}$ and weighed again. The dry pycnometer was re-filled with oil at the same temperature and weighed. The experiment was repeated three times and the mean and standard deviation were calculated. The density was determined using the following equations:

$$
\begin{aligned}
& \mathrm{W}_{\mathrm{o}}=\mathrm{W}_{\mathrm{o}+\mathrm{p}}-\mathrm{W}_{\mathrm{p}} \\
& \mathrm{W}_{\mathrm{w}}=\mathrm{W}_{\mathrm{w}+\mathrm{p}}-\mathrm{W}_{\mathrm{p}} \\
& \text { Density }=\mathrm{W}_{\mathrm{o}} / \mathrm{W}_{\mathrm{w}}
\end{aligned}
$$

Where $\mathrm{W}_{\mathrm{o}}$ = weight of oil, $\mathrm{W}_{\mathrm{w}}=$ weight of water, $\mathrm{W}_{\mathrm{p}}=$ weight of empty pycnometer, $\mathrm{W}_{\mathrm{o}+\mathrm{p}}=$ weight of empty of pycnometer + weigh of oil, $\mathrm{W}_{\mathrm{w}+\mathrm{p}}=$ weight of the empty pycnometer + weight of water (AOCS, 2011).

\subsubsection{Determination refractive index}

The refractive index of the oil was measured using an Abbe refractometer. Three drops of oil were placed on the surface a lower prism. The prism 
and mirror were adjusted until it gave the sharpest reading. The experiment was repeated twice and the mean and standard deviation were calculated (AOCS, 2011).

\subsubsection{Determination of viscosity}

The viscosity of the oil was measured using Thermo Scientific HAAKE viscotester 6 plus. About $40 \mathrm{ml}$ of oil sample were placed in a beaker and the rotor was immersed in the oil. The velocity of the instrument was adjusted to 200 rounds per min. The viscosity was read directly from the screen of the instrument. The experiment was repeated twice and the mean and standard deviation were calculated (AOCS, 2011).

\subsubsection{Determination of color}

The color of the oil was determined using a Lovibond Tintometer type 4D. Oil was placed in a standard sized glass cell and visually compared with red, yellow and natural color standards. Results were expressed in terms of numbers associated with the color of standards (AOCS, 2011).

\subsection{Chemical properties of the oils}

Acid, peroxide, and saponification values were determined following the standard methods of the AOCS Official Methods [AOCS, 2011]. In each case triplicate analyses were carried out and the mean and the standard deviation were calculated (mean $\pm \mathrm{SD}$ ).

\subsubsection{Fatty acid composition of the oils}

The fatty acid composition was confirmed according to the ISO standard ISO 5509 (ISO, 2000). Briefly, one drop of the oil was broken down in $1 \mathrm{ml}$ of n-heptane, $50 \mu \mathrm{g}$ of sodium methylate (Merck, Darmstadt, Germany) were added, and the closed tube was agitated vigorously for $1 \mathrm{~min}$ at room temperature. After the addition of $100 \mu \mathrm{L}$ of water, the tube was centrifuged at $4500 \mathrm{rpm}$ for $10 \mathrm{~min}$ and the lower aqueous phase was removed. Then $50 \mu \mathrm{L}$ of $\mathrm{HCl}(1 \mathrm{~mol}$ with methyl orange (Merck, Darmstadt, Germany)) were added, the solution was briefly mixed, and the lower aqueous phase was rejected. About $20 \mathrm{mg}$ of sodium hydrogen sulphate (monohydrate, extra pure; Merck, Darmstadt, Germany) were added, and after centrifugation at $4500 \mathrm{rpm}$ for $10 \mathrm{~min}$, the top n-heptane phase was transferred to a vial and injected into a HP5890 gas chromatograph (Agilent Technologies Sales \& Services GmbH \& Co. KG, Waldbronn, Germany), with a capillary column, CP-Sil 88 (100 m long, $0.25 \mathrm{~mm}$ ID, film thickness $0.2 \mu \mathrm{m})$. The temperature program was as follows: From $155^{\circ} \mathrm{C}$; heated to $220^{\circ} \mathrm{C}\left(1.5^{\circ} \mathrm{C} / \mathrm{min}\right), 10 \mathrm{~min}$ isotherm; injector $250{ }^{\circ} \mathrm{C}$, detector $250{ }^{\circ} \mathrm{C}$; carrier gas $36 \mathrm{~cm} / \mathrm{s}$ hydrogen; split ratio 1:50; detector gas $30 \mathrm{ml} / \mathrm{min}$ hydrogen; $300 \mathrm{ml} / \mathrm{min}$ air and $30 \mathrm{ml} / \mathrm{min}$ nitrogen; manual injection volume less than $1 \mu$ l. The peak areas were computed by the integration software, and percentages of fatty acid methyl esters (FAME) were obtained as weight percent by direct internal normalization.

\subsubsection{Determination of tocol contents of the oil}

For determination of vitamin-E-active compounds, a solution of $250 \mathrm{mg}$ of oil in $25 \mathrm{~mL}$ of $\mathrm{n}$-heptane was directly used for the HPLC. The HPLC analysis was conducted using a Merck-Hitachi low-pressure gradient system, fitted with a L-6000 pump (MerckHitachi, Darmstadt, Germany), a Merck-Hitachi F-1000 fluorescence spectrophotometer (Darmstadt, Germany; detector wavelengths for excitation $295 \mathrm{~nm}$, for emission $330 \mathrm{~nm}$ ), and a ChemStation integration system (Agilent Technologies Deutschland GmbH, Böblingen, Germany). The samples in the amount of $20 \mu \mathrm{L}$ were injected by a Merck 655-A40 autosampler (Merck-Hitachi, Darmstadt, Germany) onto a Diol phase HPLC column $25 \mathrm{~cm} \times 4.6 \mathrm{~mm}$ ID (Merck, Darmstadt, Germany) used with a flow rate of 1.3 $\mathrm{mL} / \mathrm{min}$. The mobile phase used was $99 \mathrm{~mL} \mathrm{n}$-heptane $+1 \mathrm{~mL}$ tert-butyl methyl ether (Balz, et al. 1992).

\subsubsection{Rancimat test}

Rancimat test Induction time was determined using the International Standard Organization method (ISO 6886, 2006). The oxidative stability of each sample was determined as the induction period (IP, h) recorded by a 743 Rancimat (Metrohm, Herisau, Switzerland) apparatus using $3 \mathrm{~g}$ of oil sample. The samples placed in Rancimat standard tubes were subjected to the normal operation conditions of the test by heating at $110^{\circ} \mathrm{C}$ with an air flow of $20 \mathrm{~L} / \mathrm{h}$.

\subsection{Statistical analysis}

The values reported in Tables 1 to 3 are the means \pm the standard deviations (SD) of three replicates (two replicates for viscosity and refractive index). The statistical analysis was done with SPSS 20.0. Analysis of variance (ANOVA) was used to evaluate the significance between the raw and thermally processed samples. The variant means were separated using the least significant difference method (LSD). The level of significance was set at $p<0.05$.

\section{RESULTS AND DISCUSSION}

\subsection{Proximate composition}

The results of the proximate analysis of the kernel seeds of raw and thermally processed samples are given in Table 1. As can be seen from the table, 
TABLE 1. Proximate composition of the kernels as well as the physical and chemical properties of Balanities aegyptiaca oils extracted from raw and processed kernels

\begin{tabular}{lccc}
\hline & \multicolumn{3}{c}{ Sample } \\
\cline { 2 - 4 } Component & Raw & Boiled & Roasted \\
\hline Moisture (\%) & $3.74^{\mathrm{a}} \pm 0.69$ & $3.35^{\mathrm{a}} \pm 0.21$ & $2.18^{\mathrm{b}} \pm 0.22$ \\
Ash (\%) & $2.88^{\mathrm{a}} \pm 0.13$ & $2.32^{\mathrm{b}} \pm 0.11$ & $2.92^{\mathrm{a}} \pm 0.01$ \\
Protein (\%) & $42.41^{\mathrm{a}} \pm 0.03$ & $41.80^{\mathrm{a}} \pm 0.06$ & $38.52^{\mathrm{a}} \pm 0.11$ \\
Lipid (\%) & $39.98^{\mathrm{a}} \pm 1.24$ & $38.28^{\mathrm{a}} \pm 2.20$ & $46.23^{\mathrm{a}} \pm 1.38$ \\
Total carbohydrate (\%)* & $10.99^{\mathrm{a}} \pm 1.4^{*}$ & $14.25^{\mathrm{a}} \pm 2.2^{*}$ & $10.15^{\mathrm{a}} \pm 1.4^{*}$ \\
Specific gravity & $0.9132^{\mathrm{a}} \pm 0.0006$ & $0.9138^{\mathrm{a}} \pm 0.0005$ & $0.9118^{\mathrm{a}} \pm 0.0008$ \\
Viscosity (Poise) & $63.5^{\mathrm{a}} \pm 0.73$ & $67^{\mathrm{a}} \pm 1.4$ & $66^{\mathrm{a}} \pm 3.5^{*}$ \\
RI & $1.468 \pm 0.0028$ & $1.468 \pm 0.0007$ & $1.465 \pm 0.0014$ \\
Color & $13.2 \mathrm{y}, 0.4 \mathrm{r}$ & $20.1 \mathrm{y}, 1.2 \mathrm{r}$ & $20.2 \mathrm{y}, 1.5 \mathrm{r}$ \\
Peroxide value (meq/kg) & $13.34^{\mathrm{a}} \pm 0.28$ & $18.06^{\mathrm{b}} \pm 0.46$ & $4.56^{\mathrm{c}} \pm 0.28$ \\
Acid value (mg KOH/g) & $0.30^{\mathrm{a}} \pm 0.02$ & $0.34^{\mathrm{a}} \pm 0.03$ & $0.34^{\mathrm{a}} \pm 0.00$ \\
Saponification value (mg KOH/g) & $200.31^{\mathrm{a}} \pm 2.42$ & $200.47^{\mathrm{a}} \pm 5.54$ & $203.55^{\mathrm{a}} \pm 6.31$ \\
\hline
\end{tabular}

* Values are means $( \pm S D)$. The standard deviation was calculated using propagation of error.

** Means followed by different letters within a row are significantly $(\mathrm{p}<0.05)$ different (All comparisons were made between the raw and the thermally processed samples only).

TABLE 2. Fatty acid composition of Balanities aegyptiaca oil extracted from raw and processed kernels

\begin{tabular}{lccc}
\hline & \multicolumn{3}{c}{$\%($ mean \pm SD) } \\
\cline { 2 - 4 } Fatty acid & Raw & Boiled & Roasted \\
\hline $\mathrm{C} 16: 0$ & $12.97^{\mathrm{a}} \pm 0.23$ & $12.47^{\mathrm{a}} \pm 0.00$ & $12.58^{\mathrm{a}} \pm 0.10$ \\
$\mathrm{C} 16: 1 \Delta 7$ & - & - & $0.03 \pm 0.00$ \\
$\mathrm{C} 16: 1 \Delta 9$ & $0.18 \pm 0.01$ & $0.20 \pm 0.00$ & $0.17 \pm 0.00$ \\
$\mathrm{C} 17: 0$ & $0.12 \pm 0.01$ & $0.11 \pm 0.00$ & $0.11 \pm 0.00$ \\
$\mathrm{C} 17: 1$ & - & $0.06 \pm 0.00$ & $0.06 \pm 0.00$ \\
$\mathrm{C} 18: 0$ & $13.64^{\mathrm{a}} \pm 0.08$ & $14.07^{\mathrm{a}} \pm 0.00$ & $12.98^{\mathrm{a}} \pm 0.15$ \\
$\mathrm{C} 18: 1 \Delta 9$ & $31.44^{\mathrm{a}} \pm 0.07$ & $32.51^{\mathrm{a}} \pm 0.01$ & $31.80^{\mathrm{a}} \pm 0.02$ \\
$\mathrm{C} 18: 1 \Delta 11$ & $0.80 \pm 0.00$ & $0.88 \pm 0.01$ & $0.82 \pm 0.01$ \\
$\mathrm{C} 18: 2 \Delta 9,12$ & $39.43^{\mathrm{a}} \pm 0.06$ & $38.20^{\mathrm{a}} \pm 0.01$ & $39.88^{\mathrm{a}} \pm 0.09$ \\
$\mathrm{C} 18: 3 \Delta 9,12,15$ & - & $0.06 \pm 0.00$ & $0.06 \pm 0.01$ \\
$\mathrm{C} 20: 0$ & $0.37 \pm 0.01$ & $0.38 \pm 0.01$ & $0.35 \pm 0.01$ \\
C20:1 & $0.10 \pm 0.00$ & $0.10 \pm 0.00$ & $0.10 \pm 0.00$ \\
C22:0 & - & $0.06 \pm 0.00$ & $0.06 \pm 0.01$ \\
Saturated & 27.1 & 27.09 & 26.08 \\
Monounsaturated & 32.52 & 33.75 & 32.98 \\
Polyunsaturated & 39.43 & 38.32 & 39.94 \\
\hline
\end{tabular}

* Values are means $( \pm S D)$.

** Statistical analysis was performed for the major fatty acids only. Means followed by different letters within a row are significantly $(\mathrm{p}<0.05)$ different (All comparisons were made between the raw and the thermally processed samples only).

the raw sample contained $3.72 \%$ moisture, $2.88 \%$ ash, $42.41 \%$ crude protein, $39.98 \%$ crude fat, and $10.99 \%$ total carbohydrates (obtained by difference). These results fall within the range of
TABLE 3. Tocopherol and tocotrienol (tocols) composition of Balanities aegyptiaca oil extracted from raw and processed kernels*

\begin{tabular}{lccc}
\hline & \multicolumn{3}{c}{ mg/100g } \\
\cline { 2 - 4 } \multicolumn{1}{c}{ Tocols } & \multicolumn{1}{c}{ Raw } & Boiled & Roasted \\
\hline$\alpha-\mathrm{T}$ & $23.1^{\mathrm{a}} \pm 0.2$ & $21.2^{\mathrm{a}} \pm 0.1$ & $21.4^{\mathrm{a}} \pm 0.4$ \\
$\beta-\mathrm{T}$ & $0.1 \pm 0.0$ & $0.2 \pm 0.0$ & $0.2 \pm 0.0$ \\
$\gamma-\mathrm{T}$ & $18.4^{\mathrm{a}} \pm 0.2$ & $17.95^{\mathrm{a}} \pm 0.07$ & $17.85^{\mathrm{a}} \pm 0.4$ \\
$\delta$-T & $0.6 \pm 0.0$ & $0.5 \pm 0.0$ & $0.6 \pm 0.0$ \\
Total tocopherols & 42.2 & 39.85 & 40.05 \\
$\alpha-\mathrm{T} 3$ & $0.2 \pm 0.1$ & $0.2 \pm 0.0$ & $0.1 \pm 0.1$ \\
$\beta$-T3 & $\mathrm{nd}^{* *}$ & $\mathrm{nd} \mathrm{d}^{* *}$ & $\mathrm{nd}^{* *}$ \\
$\gamma$-T3 & $0.1 \pm 0.0$ & $\mathrm{nd}^{* *}$ & $\mathrm{nd}^{* *}$ \\
$\delta$-T3 & $\mathrm{nd}^{* *}$ & $\mathrm{nd}^{* *}$ & $\mathrm{nd}^{* *}$ \\
Plastochromanol-8 (P8) & $\mathrm{nd}^{* *}$ & $\mathrm{nd}^{* *}$ & $\mathrm{nd}^{* *}$ \\
\hline
\end{tabular}

*Values are means $( \pm S D)$.

**Not detectable.

** Statistical analysis was performed for the major tocols only. Means followed by different letters within a row are significantly $(\mathrm{p}<0.05)$ different (All comparisons were made between the raw and the thermally processed samples only).

previously reported values of the chemical composition of Balanites aegyptiaca kernel seeds (Hussain, et al. 1949; Nour et al. 1985; Mohamed, et al. 2002; Chapagain et al. 2009; Manji et al. 2013). In conclusion, the findings of these studies have revealed considerable variations in the chemical composition based on various genotypes of Balanites aegyptiaca and the different origins of the analyzed samples. The lowest and the highest values reported for crude fat were $39-49.9 \%$, crude 
protein $26.1-50.37 \%$, ash $3.3-6.3 \%$, and moisture $3.1-5.7 \%$. Compared to a raw sample, thermally processed kernel seeds did not show significant ( $p>0.05$ ) changes in crude protein, crude fat, or total carbohydrates. On the other hand, the findings of the study have shown a significant difference $(p<0.05)$ in the ash content between raw and boiled samples $(2.88 \%$ for raw sample and $2.32 \%$ for boiled one). The leaching of minerals by water during the boiling process was reported by some authors (Arinola and Adesina, 2014; Hefnawy, 2011) as the main cause of this decrease in ash content. Furthermore, the moisture content of the roasted kernels changed significantly $(p<0.05)$ in comparison with the raw ones (Table 1). This variation in moisture content could be attributed to the effect of roasting which facilitates oil extraction by decreasing its viscosity, releasing oil from intact cells and removing moisture (Alenyorege, 2015).

\subsection{The physical properties of the oils}

The physical properties of the extracted oils from raw, boiled and roasted kernels are displayed in Table 1. As can be seen from the table, the crude oil of Balanites aegyptiaca is a liquid which has a light yellow color, a specific gravity of 0.9132 , a viscosity of 63.4 cpoise, and a refractive index of 1.468. The values of the specific gravity, the color, and the refractive index of the oil are in good agreement with the reported values in the literature [Hussain, et al. 1949; Nour et al.1985; Manji et al. 2013; Chapagain et al., 2009]. However, only Chapagain et al. [2009] have reported the value of the viscosity and it was observably different from the present study; $49 \mathrm{cp}$ aganist $63.5 \mathrm{cp}$ repectively. Additionaly, the results demonstrated that both roasting and boiling did not have considerable effects $(p>0.05)$ on viscosities, refractive indices, and specific gravities of the extracted oils when compared to raw one. On the other hand, boiling has intensified the color (color changes from light yellow to deep yellow) as shown in Table 1. This could probably be due to the increase in $\alpha$-carotene content as a result of thermal processing (boiling) which facilitates the distribution or extraction of $\alpha$-carotene from kernels to oils. This was clearly observed from the color of the defatted cakes of the raw (yellowish) and the boiled (off white) samples. Previous study by Hussain et al. (1949) has shown that Balanites aegyptiaca oil contains $\alpha$-carotene.

In the case of the roasted sample, the color of the oil has changed from light yellow to brownish yellow. Moreover, the color of the defatted cake was also changed to brown. The formation of brown color during roasting was noticed by some researchers (Akinoso, et al. 2011; Anjum, et al. 2006) and was explained by the formation of browning substance which results from Maillard-type nonenzymatic reactions, caramelization, and phospholipid degradation.

\subsection{The chemical properties of the oils}

The chemical properties of the oils of Balanites aegyptiaca are presented in Table 1. As can be seen from the table, with the exception of peroxide value, the chemical properties of the oil extracted from the raw kernels compare well with the previous studies (Hussain, et al. 1949; Nour et al. 1985; Manji et al. 2013). Nour et al. (1985) have analyzed the oils of two different samples of Balanites aegyptiaca seeds originating from Sudan. They have found that the saponification values were 190.05 and 176.97 , peroxide values 3.7 and 2.7 , and acid values 0.40 and 0.50 , respectively. Similarly, Manji et al. (2013) reported that the saponification and the peroxide values for Balanites aegyptiaca oil were 168.6 and 6.0 , respectively.

The results also showed that the peroxide values of the oil from thermally processed seeds changed significantly $(p<0.05)$. Compared to the oil from the raw sample, the peroxide value of the oil from the roasted sample decreased drastically $(\mathrm{p}<0.05)$; whereas a considerable increase $(p<0.05)$ in the peroxide value of the oil from the boiled sample was noticed. The drastic change in peroxide value in the boiled sample is probably due to the increase in oxidation of the oil caused by heating (boiling) which accelerates the oxidation processes as well as the hydrolysis in an aqueous medium which also increases the rate of rancidity. In contrast to boiling, the considerable decrease in peroxide value for the oil of the roasted seeds could be due to the formation of some materials which inhibit the oxidation of the oil. Roasting of seeds prior to oil extraction has been reported in some articles (Wijesundera, et al. 2008; Abou-Gharbia, et al. 1996) to enhance the oxidative stability of oils. In contrast, some authors have found that roasting has a negative effect on the oxidative stability of oils extracted from roasted seeds (Mariod, et al. 2012; Anjum, et al. 2006). Wijesundera et al. (2008) have reported that the roasting (at $165{ }^{\circ} \mathrm{C}$ for $5 \mathrm{~min}$ ) of canola and mustard seeds increased the oxidative stability of the extracted oils and did not affect the content of tocopherols. The enhancement in oxidative stability of canola oil was attributed to the formation of 2,6-dimethoxy-4-vinyl phenol (DMVP) during roasting.

\subsection{Fatty acid composition of the oils}

Table 2 displays the fatty acid composition of Balanites aegyptiaca oils. It is apparent that linoleic (average $31.92 \%$ ), oleic (average $39.17 \%$ ), stearic (average $13.56 \%$ ), and palmitic 
(average $12.68 \%$ ) acids are the major fatty acids of the oils which collectively represent about $97 \%$ of the total acids. Moreover, the unsaturated fatty acids constitute about $71 \%$ of all the fatty acids present in the oils. The monounsaturated fatty acids represent an average value of $32.52 \%$, whereas the polyunsaturated fatty acids reach an average value of $39.43 \%$. The higher content of the unsaturated fatty acids is favorable from a nutritionist's point of view, although it is inferior with respect to oxidative stabilities of the oils because higher levels of unsaturation (level of polyunsaturated fatty acids specifically) is more susceptible to oxidation. Generally, the rate of oxidation was found to increase with the increase in the number of double bonds in the fatty acids (Kamal-Eldin, 2006; Savage, et al. 1999). Savage et al. (1999) have studied the oxidative stability of different samples of Walnut oil. The results revealed the presence of a correlation between the levels of C18:2 fatty acid in the oil and the reduction in the oxidative stabilities of the oil. Compared to the oil extracted from the raw sample, the fatty acid composition of the oil extracted from the processed samples remained roughly unchanged. The present results of the fatty acid composition of Balanites aegyptiaca oil are in good agreement with previous studies (Al Ashaal, et al. 2010; Chapagain, 2009; Hussain, et al. 1949; Mohamed, et al. 2002; Nour et al.1985) regarding the major fatty acids in the oil, however, except for Nour et al. (1985), significant variations in the percentages of these acids could be noticed. The noticeable variations in the percentages of fatty acids were clarified by Chapagain et al. (2009) who analyzed the fatty acid composition of six Balanites aegyptiaca genotypes. The percentage ranges of the four major fatty acids were found to be: palmitic acid $12.7-16.0 \%$, stearic $10.2-12.1 \%$, oleic acid $23.5-43.7 \%$, and linoleic acid $31.50-51.6 \%$. Moreover, the present study is the first study to report the presence of cis-vaccenic $(0.80-0.88 \%)$, margaric (0.11-0.12\%), and eicosenoic (gondoic) $(0.1 \%)$ acids in Balanites aegyptiaca oil.

\subsection{Tocol contents of the oil}

The tocopherol and tocotrienol (tocols) compositions of the oil of Balanites aegyptiaca are given in Table 3. It is obvious that $\alpha$ - and $\gamma$ tocopherols represent the major constituents of tocols although traces or very little quantities of $\delta$-tocopherols were also detected. The total tocopherol contents of the oil extracted from the raw, boiled, and roasted samples were found to be $42.2 \mathrm{mg} / 100 \mathrm{~g}, 39.85 \mathrm{mg} / 100 \mathrm{~g}$, and 40.05 $\mathrm{mg} / 100 \mathrm{~g}$, respectively. Tocopherols were reported in the literature (Kamal-Eldin, 2006) as one of the essential components of vegetable oil which have activity against oxidation or the development of rancidity. Compared to the values of tocopherol contents in vegetable oil and industrial fats investigated by Schwartz et al. (2008), the tocopherol content of Balanites aegyptiaca oil is higher than coconut oil, refined olive oil, and extra virgin olive oil and is comparable to sesame oil. In addition, it is observably lower than sunflower oil, rapeseed refined and cold pressed oil, camelina oil, and wheat germ. Furthermore, the results have revealed the absence of tocotrienols as well as plastochromanol-8 (P8) although trace quantities of $\alpha$ - and $\gamma$-tocotrienols were detected in some samples (Table 3).

\subsection{Oxidative stability of Balanites aegyptiaca oil}

The oxidative stability of the oil is expressed as the induction period (IP) and was determined by Rancimat at $110{ }^{\circ} \mathrm{C}$. The oxidative stability of the oil extracted from the raw kernels was $10.64 \mathrm{~h}$. The highest stability was shown by the oil from the roasted sample $(14.50 \mathrm{~h})$ whereas the lowest stability was displayed by the oil from the boiled sample $(7.14 \mathrm{~h})$. It has been reported in the literature that the oxidative stability of vegetable oil depends on its fatty acid composition and the antioxidants (mainly tocopherols) (Kamal-Eldin, 2006). However, in the present study, these variations were not seen because of the differences in fatty acid compositions or tocol contents as their values remain fairly unchanged between the oil from the raw and the processed samples. Possibly these differences could be due to the presence of other antioxidants or might be due to the effect of boiling which accelerates the oxidation of the oil. The peroxide values for the oil confirm this assumption.

\section{CONCLUSIONS}

The present study reveals that the roasting of Balanites aegyptiaca kernels prior to oil extraction has positively improved the oxidative stability of the oil (from 10.64 hours for raw to 14.50 hours for roasted), and significantly $(\mathrm{p}<0.05)$ reduced the peroxide value (from $13.34 \mathrm{meq} / \mathrm{Kg}$ for raw to $4.56 \mathrm{meq} / \mathrm{Kg}$ for roasted), and with the exception of color, did not change the other physical and chemical properties in a significant way $(p>0.05)$. In addition, the findings displayed that the oil contains significant levels of essential fatty acids and tocopherols. The observable higher levels of unsaturated fatty acids $(71 \%)$ demonstrates the benefits of the oil for human consumption. Further study regarding the existence of phenolics, saponins, carotenoid compounds as well as the compounds formed or chemically modified as a result of roasting is required. 


\section{REFERENCES}

Abou-Gharbia HA, Shahidi F, Shehata AAY, Youssef MM. 1996. Oxidative stability of extracted sesame oil from raw and processed seeds. J. Food Lipids 3, 59-72. http://dx.doi. org/10.1111/j.1745-4522.1996.tb00054.x

Akinoso R, Aboaba SA, Olajide WO. 2011. Optimization of roasting temperature and time during oil extraction from orange (Citrus sinensis) seeds: A response surface methodology approach. African J. Food Agri. Nutr. Develop. 11, 5301-5317.

Al Ashaal HA, Farghaly AA, Abd El Aziz MM, Ali MA. 2010. Phytochemical investigation and medicinal evaluation of fixed oil of Balanites aegyptiaca fruits. J. Ethnopharmacol. 127, 495-501. http://dx.doi.org/10.1016/j.jep.2009.10.007

Alenyorege EA, Hussein YA, Adongo TA. 2015. Extraction yield, efficiency and loss of the traditional hot water floatation (HWF) method of oil extraction from the seeds of Allanblackia Floribunda. Inter. J. Sci Technol. Res. 4, 92-95.

American Oil Chemists' Society (AOCS). 2011. Official methods and recommended practices of the American Oil Chemists' Society, 4th edn. AOCS, Champaign, IL.

Anjum F, Anwar F, Jamil A, Iqbal M. 2006. Microwave roasting effects of the physico-chemical composition and oxidative stability of sunflower seed oil. J. Am. Oil Chem. Soc. 83, 777-784. http://dx.doi.org/10.1007/s11746-006-5014-1

AOAC 1990. Official methods of analysis of the Association of Official Analytical Chemists' $15^{\text {th }}$ Edition. Washington, DC. Association of Official Analytical Chemists

Arinola SO, Adesina K. 2014. Effect of thermal processing on the nutritional, antinutritional and antioxidant properties of Tetracarpidium conophorum (African walnut). J. Food Proc. 1-4. http://dx.doi.org/10.1155/2014/418380

Balz M, Schulte E, Thier HP. 1992. Trennung von Tocopherolen und Tocotrienolen durch HPLC. Eur. J. Lipid Sci. Technol. 94, 209-213. http://dx.doi.org/10.1002/lipi.19920940604

Chapagain BP, Yehoshua Y, Wiesman Z. 2009. Desert date (Balanites aegyptiaca) as an arid lands sustainable Bioresource for biodiesel. Biores. Technol. 100, 1221-1226. http://dx.doi.org/10.1016/j.biortech.2008.09.005

Cheng W-Y, Akanda JMdH, Nyam K-L. 2016. Kenaf Seed Oil: A Potential New Source of Edible Oil: Review. Trends in Food Sci. Technol. 52, 57-65. https://doi.org/10.1016/j. tifs.2016.03.014

El Amine HM. 1990. Trees and Shrubs of the Sudan. Ithaca Press, England.

Hefnawy TH. 2011. Effect of processing methods on nutritional composition and anti-nutritional factors in lentils (Lens culinaris). J. Agric. Sci. 56, 57-61. https://doi.org/10.1016/j. aoas.2011.07.001

Hussain SA, Dollear FG, O'connor RT. 1949. Oil from the kernels of lalob fruit, Balanites aegyptiaca. J. Am. Oil Chem. Soc. 26, 730-732. http://dx.doi.org/10.1007/BF02903182
ISO 5509:2000 Animal and Vegetable Fats and OilsPreparation of Methyl Esters of Fatty Acids; International Standard ISO 5509:2000; ISO: Geneva, Switzerland, 2000.

ISO 6886, 2006. Animal and vegetable fats and oils. Determination of oxidative stability (accelerated oxidation test).

Kamal-Eldin A. 2006. Effects fatty acids and tocopherols on the oxidative stability of vegetable oils. Eur. J. Lipid Sci. Technol. 58, 1051-1061. http://dx.doi.org/10.1002/ejlt.200600090

Manji AJ, Sarah EE, Modbbo UU. 2013. Studies on the potential of Balanites aegyptiaca seed oil as raw material for the production of liquid cleansing agents. Int. J. Phys. Sci. 8, $1655-1660$.

Mariod AA, Ahmed SY, Abdelwahab SI, Cheng SF, Eltom AM, Yagoub SO, Gouk SW. 2012. Effects of roasting and boiling on the chemical composition, amino acids and oil stability of safflower seeds. Inter. J. Food Sci. Technol. 47, 1737-1743 http://dx.doi.org/10.1111/j.1365-2621.2012.03028.x

Mariod AA, Matthäus B, Eichner K. 2004. Fatty acid, tocopherol, and sterol composition as well as oxidative stability of three unusual Sudanese oils. J. Food Lipids 11, 179-189. http://dx.doi.org/10.1111/j.1745-4522.2004.01131.x

Maydell HJVon. 1990. Trees and Shrubs of the Sahel: Their Characteristics and Uses. Verlag Josef Margraf, Scientific Books, Germany.

Mohamed AM, Wolf W, Spieb WEL. 2002. Physical, morphological and chemical characteristics, oil recovery and fatty acid composition of Balanites aegyptiaca Del. Kernels. Plant Foods Hum. Nutrit. 57, 179-189. http://dx.doi. org/10.1023/A:1015237612018

Ndidi US, Ndidi CU, Aimola IA, Bassa OY, Mankilik M, Adamu Z. 2014. Effects of Processing (Boiling and Roasting) on the Nutritional and Antinutritional Properties of Bambara Groundnuts (Vigna subterranea [L.] Verdc.) from Southern Kaduna, Nigeria. J. Food Proc. ID 472129, http://dx.doi.org/10.1155/2014/472129

Nour AAM, Ahmed AR, Abdel-Gayoum AA. 1985. A Chemical study of Balanites Aegyptiaca L. (Lalob) fruits grown in Sudan. J. Sci. Food Agric. 36, 1254-1258. http://dx.doi. org/10.1002/jsfa.2740361208

Savage GP, Dutta PC, McNeil DL. 1999. Fatty acid and tocopherol contents and oxidative stability of Walnut oils. J. Am. Oil Chem. Soc. 76, 1059-1063.

Schwartz H, Ollilainen V, Piironen V. 2008. Tocopherols, tocotrienols and plant sterol contents of vegetable oils and industrial fats. J. Food Comp. Anal. 21, 152-161. http://dx.doi. org/10.1016/j.jfca.2007.07.012

Vermaak I, Kamatou GPP, Komane-Mofokeng B, Viljoen AM, Backett K. 2011. African seed oils of commercial importance-Cosmetic applications. South Afric. J. Botany 77, 920-933. http://dx.doi.org/10.1016/j.sajb.2011.07.003

Wijesundera C, Ceccato C, Fagan P, Shen Z. 2008. Seeds roasting improves the oxidative stability of Canola (B. napus) and Mustard (B. juncea) seed oils. Eur. J. Lipid Sci. Technol. 110, 360-367. http://dx.doi.org/10.1002/ejlt.200700214 